\title{
The use of aquatic environments for Scientific Education purposes: the case of the Imboassica Lagoon, Macaé, RJ
}

\author{
O uso de ambientes aquáticos para a Educação Científica: \\ o caso da Lagoa Imboassica, Macaé, RJ
}

\author{
Laísa Maria Freire dos Santos ${ }^{1}$, Erica Steagall ${ }^{1}$, Deia Maria Ferreira ${ }^{2}$, \\ Francisco de Assis Esteves ${ }^{1}$ and Reinaldo Luiz Bozelli ${ }^{1}$
}

\begin{abstract}
${ }^{1}$ Laboratório de Limnologia, Departamento de Ecologia, Instituto de Biologia, Universidade Federal do Rio de Janeiro - UFRJ, Ilha do Fundáo, CCS, Bl. A, CEP 21941-902, Rio de Janeiro, RJ, Brazil e-mail: laisa@biologia.ufrj.br, steagall.erica@gmail.com, festeves@biologia.ufrj.br, bozelli@biologia.ufrj.br ${ }^{2}$ Departamento de Ecologia, Instituto de Biologia, Universidade Federal do Rio de Janeiro - UFRJ, Ilha do Fundão, CCS, Bl. A, CEP 21941-902, Rio de Janeiro, RJ, Brazil e-mail: deia@biologia.ufrj.br
\end{abstract}

\begin{abstract}
Aim: The present work aims to discuss the potential use of aquatic environments for teaching purposes, taking the Imboassica Lagoon and its environmental problems as an example. Methods: A case study method including a literature review focused on Limnology and Science Education fields (SE). The case study was developed by describing and evaluating activities performed in the Imboassica Lagoon, considering contemporary SE approaches. Major Results: We featured environmental problems in the Imboassica Lagoon and discussed questions related to facing the problems and the construction of educational processes that generate concepts able to change reality. The activities performed in the Imboassica Lagoon provided the opportunity to set a discussion among teachers and students about different themes related to coastal lagoons' ecology based on a politicized SE viewpoint. Among some of the key aspects related to the practices performed, we could identify: the partnership between universities and schools; the contribution to develop individuals aware of citizen senses, integrating aspects of science, technology and society in field activities. The following limits were identified: the need to develop an integrated action with the school curriculum and the need to develop a plan of action with the active participation of elementary school teachers. Conclusions: The current study presented challenges for the limnologists, in order to reflect upon the social implications of their research practice seeking interaction with other sectors of society and other knowledge fields, to enhance the horizons of scientific education.
\end{abstract}

Keywords: scientific education/literacy, aquatic environment management, citizen formation, science, technology and society approach.

Resumo: Objetivo: $\mathrm{O}$ presente estudo tem o objetivo de discutir o potencial de uso dos ambientes aquáticos para fins de ensino, utilizando a lagoa Imboassica e seus problemas ambientais como caso. Métodos: Foi realizada uma revisão de literatura a partir das áreas de limnologia e de Educação em Ciências (EC). Para explorar o caso, atividades de ensino na lagoa Imboassica foram descritas e avaliadas, considerando abordagens contemporâneas da EC. Principais Resultados: Caracterizamos os problemas ambientais da lagoa Imboassica e discutimos questôes relacionadas ao seu enfrentamento e à construção de processos educativos que gerem conhecimentos capazes de modificar a realidade social. As atividades realizadas na lagoa Imboassica oportunizaram a discussão com professores e alunos sobre diferentes temas relacionados às lagoas costeiras baseados em uma visão política da alfabetização científica. Dentre os potenciais das práticas realizadas pudemos identificar: relação entre universidade e escola; contribuição para a formação de indivíduos enquanto cidadáos e integraçáo dos aspectos de ciência, tecnologia e sociedade em atividades de campo. Os seguintes limites foram identificados: a necessidade de desenvolvimento de uma ação integrada com o currículo escolar e a necessidade de desenvolver um planejamento de açóes com a participação ativa dos professores da escola básica. Conclusóes: $\mathrm{O}$ presente estudo apresentou desafios aos limnólogos, no sentido de refletir sobre as implicaçôes sociais das suas práticas de pesquisa e de buscar interação com outros setores da sociedade e com outras áreas do conhecimento, ampliando os horizontes da educação científica.

Palavras-chave: educação científica, gestão de ambientes aquáticos, formação cidadã, abordagem ciência, tecnologia e sociedade. 


\section{Introduction}

The present paper aimed to set a discussion on teaching about environmental problems faced by coastal environ in the northeast region of the state of Rio de Janeiro - Brazil. We used the specific case of the Imboassica Lagoon in Macaé - RJ, in order to develop a scientific literacy (SL) process, based on a contemporary viewpoint. Contemporary Science Education (SE) also tends to incorporate the concept of Science as a social construction, highlighting the importance of developing a "citizen like" SL procedure in order to meet daily life realities (Roberts, 2007; Santos, 2008; Sauvé, 2010). This vision is related to a number of Science Techonology and Society (STS) approaches which have a critical comprehension about the STS interactions considering tensions between democratic and technocratic demands (Auler, 2011).

The Imboassica Lagoon is located on the southern part of the city of Macaé - RJ, on the border between the municipalities of Macaé and Rio das Ostras. The margin of the lagoon facing Rio das Ostras is basically covered by grazing areas, whereas the one facing Macaé presents margins already impacted by urban settlements developed without any planning or infra-structure such as sewage systems. Part of the lagoon's basin is used for industrial activities, reflecting changes caused by the Petrobras' facility which was installed in the city in the 1970's.

We have started from the point where the Imboassica Lagoon hosts a surrounding community which can possibly get involved in the water body's management by means of specific school scientific practices. Therefore we greatly considered the relevance of SE matters as well as the elaboration of a proposal for developing outdoor activities to be performed along with high schools, undergraduate students and teachers facing water resources' management. We argue that school practices can improve subjects' performance in environmental matters. Such practices can get them involved in related management actions. It takes place when environmental matters are an open discussion in the schools in order to promote SL as a way to achieve citizenship through SE (Santos, 2007). Besides that, we argue that the undergraduate students could have an interdisciplinary dialog during their formation as ecologists in limnology. Thus, the present work aims to discuss the potential use of aquatic environments for teaching purposes. The Imboassica Lagoon was taken as a case of outside the classroom experience in order to demonstrate its environmental problems under a water resources' management framework.

We agree with Praia et al. (2007) when they state that the mentioned participation of the citizen demands a minimum scientific formation that enables the comprehension of the problems and confronting options. This starting point allows understanding SL as an "essential dimension of a citizenship culture in order to face the serious problems humanity will have to face today and in the future" (Praia et al., 2007). This point of view is in opposition to approaches that consider SL an "unrealizable myth" (SHAMOS, 1995), but on the contrary, considers that SL must be orientated to a citizen formation. The SL must be a dense intersection of the educational and of the science and technology policies, aiming to enhance the resources of formal and non formal education as a strategy for the improvement of education in general and in the formation of citizens for life in society (UNESCO, 2011).

\section{Methodology}

The present work is a case study (Stake, 1998; Yin 2001). We understand a case as a situational system generated between institutions and actors. The case study investigation faces unique technical situation and is based on different sources involving a detailed description of the case. The delineation of the case was the promotion of outdoor activities at the Imboassica Lagoon. The case was studied based on documents - activity reports - and participatory observation by the authors of the case related to the period of the development of - 2000 to 2010. The categories of analysis and description were: (i) actors involved, (ii) participation, (iii) STS approach. Actors involved were identified as the University, basic school students ${ }^{1}$, ecology bachelor degree and science teacher degree students (undergraduate) in initial formation, and science teachers (ongoing training).

The case description was done through a literary review focusing on limnology fields and SE, also describing activities performed in the Imboassica Lagoon, evaluating them according to contemporary viewpoints over the SE approach (Sauvé, 2010; Santos, 2011). At the end, we brought up some questions aiming to better apply such approach to other contexts. The Imboassica Lagoon and its matters were chosen as an example because

${ }^{1}$ Basic school students refers to elementary, middle and high school students. 
our research group has been studying the lagoon for more than two decades.

\section{Results and Discussion}

\subsection{Characterization of the Imboassica Lagoon's environmental matters}

Due to their multiple uses, coastal lagoons are among the most impacted ecosystems in Brazil (Esteves, 1998). Some of the factors that contribute to their degradation are: domestic and industrial effluents discharge, margins' landfill, the river basin's silting, sand extraction, vegetation degradation along the tributaries reaching into the lagoon and its margins, exotic fish species introduction and the buildings set along the margins (Esteves, 1998). Lagoons can work as natural filters due to the retention of inorganic particles, organic material and pollutants for long periods of time, therefore becoming environments vulnerable to organic and inorganic pollution processes (Petrucio, 1998).

The Imboassica Lagoon is located in the city of Macaé-RJ. Along the decades of 1980 and 1990 it presented features that changed due to its ongoing degradation. It rated $1.09 \mathrm{~m}$ mean depth, $2.0 \mathrm{~m}$ maximum depth and an area of $3.26 \mathrm{~km}^{2}$. The lagoon's basin covers an area of $50 \mathrm{Km}^{2}$ (Panosso et al., 1998). The Imboassica lagoon had oligohaline characteristics and was considered a well-buffered environment because of its alkalinity. Such feature is attributed to the ocean's strong influence. It presented clear waters in the past, allowing the development of bentonic macrophyte communities generated by algae from the Characeae family - an important group to this ecosystem's metabolism (Petrucio, 1998).

The lagoon's origin is related to the development of sand bars along the coast line, they provide dam systems to the Imboassica River when it seeks for an exit to the sea (Panosso et al., 1998). The river's surroundings host houses and buildings as well as industrial facilities along its final stretch before it reaches the lagoon. Due to such massive occupation developed without any planning and facing no water and sewage system, the lagoon presents nowadays high eutrophication levels.

Impacts caused by strong landfill processes - which began during the 1970's - along its margins generated a $6 \%$ loss of its area (Esteves, 1998). A residential condominium was built on part of a reclaimed area (Condominio Mirante da Lagoa). The landfills have destroyed important littoral and benthonic habitats. From 1969 up to
1994, the natural flooding area was reduced to $63 \%$ (Santos et al., 1998). The impacts suffered, due to silting, have reduced its water column and are also originated in the Imboassica River basin. The silting is caused by particulate material transportation. Such processes are related to river shorelines' deforestation. It revolves the soil in the catchment area, exposing it, especially during summer, during the rainy season. Such sediment carrying capacity can be remarkably increased by artificial sandbar openings that speed up the water flow coming from the Imboassica River basin (Esteves, 1998). As shallower spots are formed, a colonization process is triggered in the new areas when aquatic macrophytes expand the regions occupied by such plants (Palma-Silva, 1998).

Domestic sewage discharged into the Imboassica Lagoon has been causing artificial eutrophication. At first, this fertilization process increases the amount of microscopic algae whose biomass is just partially consumed by the food chain. The rest of it dies or is stored in the sediment, as organic detritus. Such factors interfere in the aquatic ecosystem metabolism, increasing decomposition rates, consuming large amounts of oxygen from the water, recycling nutrients that fertilize the water column, and increasing algae biomass. The process generates toxic gases such as methane and hydrogen sulfide. Due to such artificial eutrophication processes, fish mortality frequently takes place, pointing towards a coastal lagoon's ultimate ecological degradation (Esteves, 1998). Sanitation issues also prevent the lagoon's use for any other activities such as tourism and leisure, due to the risk of spreading illnesses such as skin diseases, diarrhea, hepatitis, cholera among others (Esteves, 1998).

Artificial sandbar openings greatly impact the ecosystem and usually happen because of intense rainfall (between November and March), when the shore gets flooded and water seeps into drain/sewage systems and into the houses along the original shoreline. Sandbar openings drastically decrease the water volume in the lagoon, draining it into the sea, exposing the lacustrine sediment, causing aquatic communities total or partial loss.

Besides limnological characterization, some educational studies analyzed water issues, showing relevant environmental problems related to management. Perceptions from environmental technicians and public school teachers, from 13 coastal municipalities in the state of Rio de Janeiro, point towards problems related to water, stating that they are the most frequent ones (37.14\%). 
Regarding such information, the most common problems were: sewage disposal, rivers and lagoons silting and all sorts of, water bodies' degradation (Pacheco et al., 2008). Silva et al. (2009) also concluded that the theme "water" was relevant in order to face the environmental problems found in the coastal area in the state of Rio de Janeiro.

Such questions are related to the need of facing the problems and developing educational processes able to change the perception of reality. It starts by identifying the problem and the conditions that allowed its establishment and how to overcome it. Educational processes can develop socio-environmental discussions that can lead to a transforming and critical view over reality, motivating people to get involved with environmental problem solving. Understanding water resource's dynamics is extremely important for its proper use and management, and it will happen based on sustainable ways.

\subsection{Dealing with environmental problems in coastal environment: the Imboassica Lagoon as a case}

Considering the substantial role played by the awareness of ecosystems' structure and functioning as a starting point for getting involved in its conservation, by the late 1990 's, limnologists began to set a relationship with schools, aiming to put students and teachers in closer contact with regional ecosystems. By researching and reflecting (Lopes and Bozelli, 2004; Bozelli et al., 2004; Esteves et al., 2005; Marsico et al., 2005) about the experience, it was possible to outline some ways to deal with environmental problems in coastal environment. Today we understand that besides the leitmotiv "to know to preserve", which motivated limnologists' pioneer action taking, it is also important to achieve collective participation in political processes related to the environmental sphere.

\subsubsection{Students, teachers and limnologists}

Between 2004 and 2007, the activity known as "Imboassica Lagoon: a classroom", provided the opportunity to set debates with high school students, highlighting a broad range of themes related to the ecology of coastal lagoons (Marsico et al., 2005). Taking the students to the lagoon's shores, puts them right in front of inevitable topics as well as facing their importance for society. Some of these themes regard degradation factors and river basin management strategies. It forces them to find out the existing environmental problems in the Imboassica lagoon and relate them to the industrialtechnological development in the city of Macaé. The activity aims to motivate the participants to get engaged in discussions and actions regarding the lagoon's problems in and outside the school environment.

The activities were performed in three spots of the Imboassica Lagoon (Figure 1): (i) the final extension of the Imboassica River, just before it reaches the lagoon; (ii) the Condominio Mirante da Lagoo and (iii) the lagoon's sandbar. The activities fulfilled a complete school period (morning or afternoon) and, at the end of each activity, monitors (undergraduate students) set their evaluations. Activities with basic school students did not have a pre-defined time frequency, on the contrary they were required by the school. The activities with teachers and undergraduate students were semiannual. At the Imboassica River - firstly, participants observed the river reaching the lagoon.

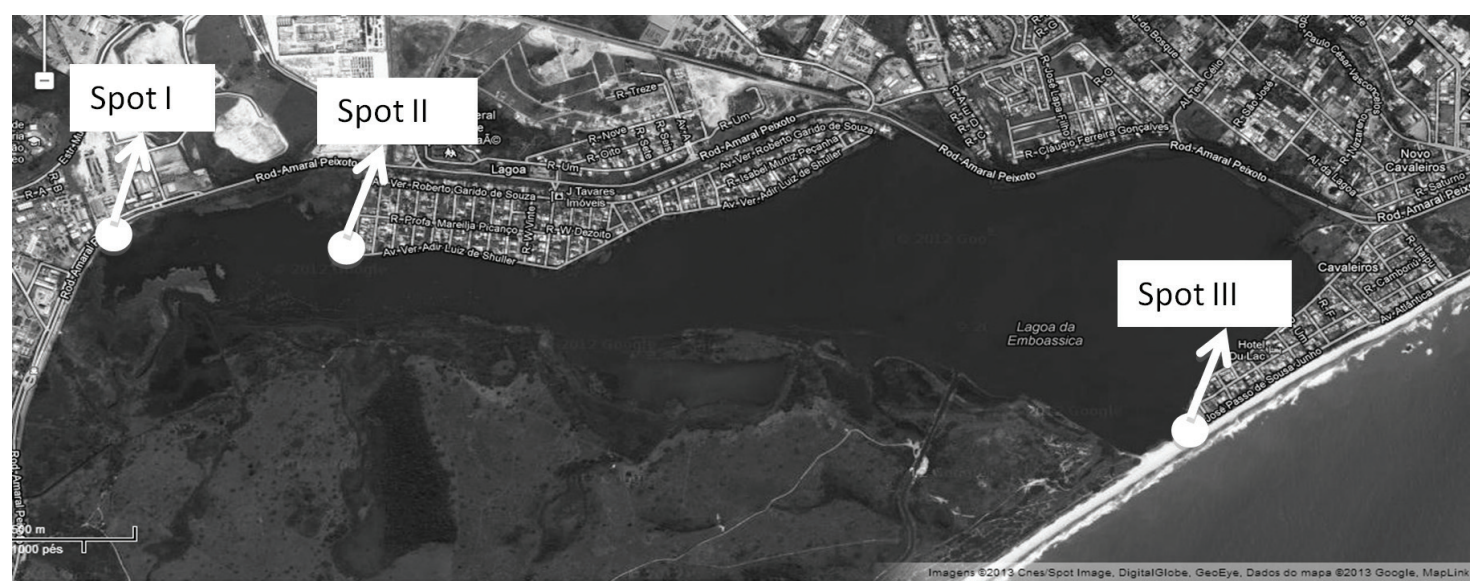

Figure 1. Imboassica Lagoon - Surrounded by residential and grazing areas and cut by the highway Rodovia Amaral Peixoto - RJ 106. Spots where activities were performed. Source: Google Earth. Access in 09/02/2013. 
Concepts such as: the river formation, catchment area, management elements and legislation were brought up.

- At the Condominio Mirante da Lagoa - at this point, some issues related to the Lagoon's surroundings occupation were discussed, aiming to point out ecological features (the lagoon's region, the macrophytes, water features, fauna and flora) and to show the existing anthropic impacts (sewage discharge, landfills, dredged areas, buildings). A technical proposal regarding the development of an alternative sewage treatment plant to reduce organic matter, phosphorus and nitrogen in the sewage - using aquatic macrophytes - was also discussed. Some political aspects involved in this particular matter were debated, once it is important to frequently explain to the students that, in spite of the existing technical solutions, the problems are not solved due to bad administration, corruption and political difficulties;

- The lagoon's sandbar - finally, other impacts were discussed focusing on the sandbar openings in the lagoon and their consequences to the ecological communities living in the lagoon and to the people who use it. We performed dialogued lectures about the themes, some posters displaying technical information about the environment and charts with outcomes from earlier researches were used to help promote the debate. It was the right moment to discuss that society stands for different interests in terms of environmental resources' use. Propositions aiming to face such issues as well as individual and collective action perspectives were also brought up. The discussions occurred with the participants gathered in a circle and with the help of banners containing information about the research developed. Similarly to what happened during teachers' ongoing courses for elementary, middle and high school teachers, students performed activities at the Imboassica Lagoon.

Between the years of 2000 and 2012, 28 teaching courses were performed, rating around 1200 participants. These courses described by Ferreira (1998) Lopes and Bozelli (2004) were planned by students of a Biological Sciences teacher's degree course under the orientation of university teachers for teachers of basic school (Bozelli et al., 2011). These were configured as an elective discipline. Bozelli et al. (2011) state that the integrated approach between graduation discipline and ongoing formation course for teachers contributes not only for the teacher's training which already work in the classroom, but also for the initial training of new teachers.

During each course, five ecosystems were visited in Macaé. One of them was the Imboassica Lagoon. We observed that some teachers started to plan this kind of activities with their students, achieving a much more political outlook in their classes, when addressing environmental issues (Figure 2). These actions were observed by the university researchers during their routine at field research and were also reported by the teachers, during ongoing formation courses, to the university teachers.

As a result, such kind of interaction, aiming to improve the Imboassica Lagoon's care, led to a reflection regarding the role played by citizens in environmental managing, taking part in discussions
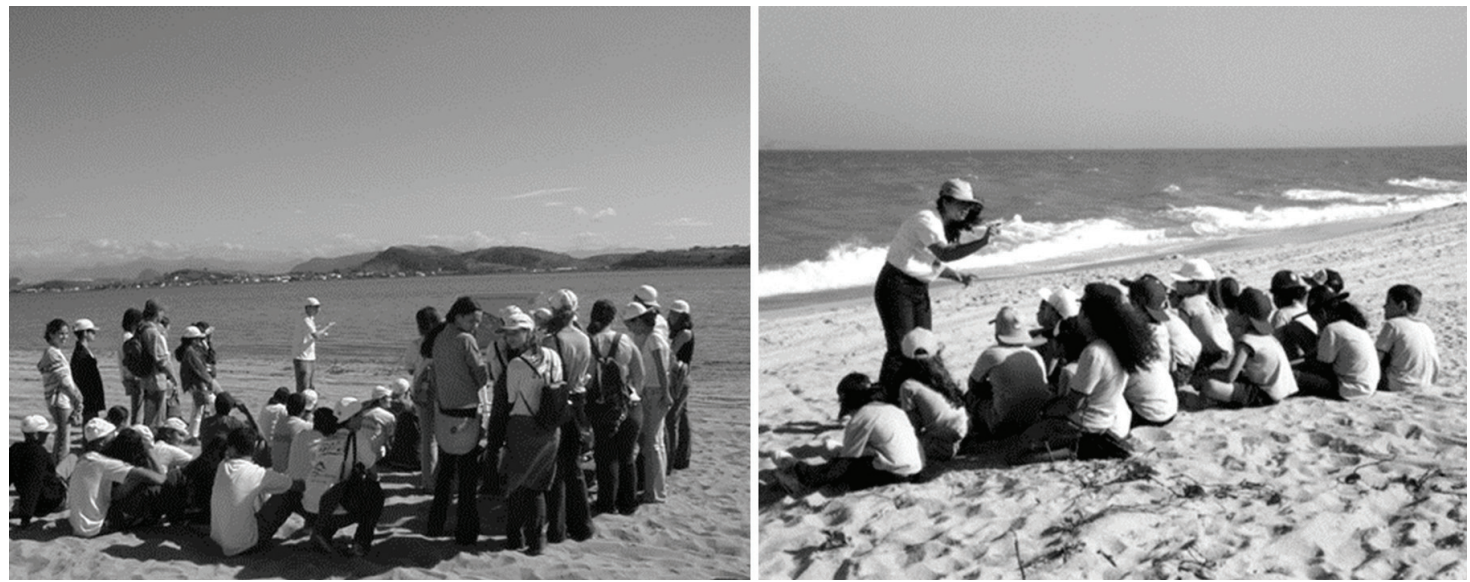

Figure 2. Imboassica Lagoon as a Classroom. Left: Activities at Imboassica Lagoon performed by limnologists for basic school's teachers. Right: Outdoor activities performed by basic school teachers with their students. 
about the lagoon in the Imboassica's Technical Chamber Workgroup (Câmara Técnica da Lagoa Imboassica). There was a moment to share the ideas brought by the teachers, which occurred during each course during the discussion of each theme. Some locals from the neighborhood spoke up and shared their experiences about sandbar openings as well as about precarious sanitation systems. These actions were also observed by the university researchers and were also reported by the teachers during the ongoing formation courses to the university teachers.

\subsubsection{Forming Ecologists: the Freshwater Ecology} subject

Since the UFRJ Limnology lab was launched in 1989, the subject Freshwater Ecology has been offered on a yearly basis, for groups of students in Ecology. Moreover, since 1992, the subject is addressed in Macaé - RJ. It holds intensive dynamics, emphasizing practical and field work. Based on such profile, it has been possible to put students in contact with Limnology, by means of a concrete panorama which they are able to recognize, once visiting the aquatic environments in the region. Such scenario shows the preserved Jurubatiba National Park area as a good example of protected environment. In opposition to it, the Imboassica Lagoon is presented as an example of a highly degraded environment. Initially, we took the students to a more restricted perspective, guided by the Secchi disc, a pH measurement, the total phosphorus concentrations, etc. From this moment and further on, students get to control some basic science tools used to understand aquatic environments. In addition, they could understand that the Imboassica Lagoon is an environment very close to its end. The next step is fulfilled by the students themselves. They get to understand the evident degradation process seen in the analyzed sample, remembering, for example, the need for conventional solutions such as sewage treatment. Thus, students are motivated to meet technologies and alternative solutions, as well as to monitor data in order to reassert the scientific results. At this point, students face a broader perspective, going beyond water sample analysis or data collection. They start to observe the lagoon's margins, its surroundings and catchment areas. Issues related to aquatic environmental managing are then introduced. It is the time to speak about law regulations, social actors as well as about the river basin and its management committee. We speak about conflicts, omissions and injustices. Once laying on different approaches such as interviews, newspaper articles and lectures, students could improve their knowledge about the Imboassica Lagoon's case and get to know the social actors involved in it. Usually, the process ends up in intense debates clearly addressing that the ongoing aquatic environments' degradation happens not because of lack of technical solutions but due to the absence of public policies and to citizen's poor participation in the decision-making processes. The basis for technical and scientific solutions lays on a politicized view over the SL, which allows matching environmental issues to its background and context, as well as guessing about its extension, solution possibilities, clearly recognizing people's role on the whole. This proposal of the scientist's formation is under the premise of a more extensive formation of the researcher that relates social matters to ecology teaching.

\subsection{Analyzing the performed activities}

By analyzing the performed practices, some potentials and limits are pointed out (Table 1). Such aspects should be overcome so that educational actions could lead to citizens' participation in environmental managing.

Discussions about aquatic ecology and its anthropic pressures, goes beyond the academia. It puts teachers and basic school students in direct contact with researchers as well as with the university routine, with undergraduate and graduate students, pushing up an interdisciplinary discussion. The partnership among universities and schools allow the development of collaborative practices that, in the long run, leads to a better quality of

Table 1. Limits and possibilities indicated in the case studied from the analyzed categories.

\begin{tabular}{|c|c|c|c|}
\hline & Categories & Identified Potentials & Identified limits \\
\hline (i) & Involved actors & $\begin{array}{l}\text { The partnership between universities and } \\
\text { schools }\end{array}$ & Conducting of the activities by the university \\
\hline (ii) & Participation & $\begin{array}{c}\text { The contribution to develop the individuals' } \\
\text { awareness of their citizenship }\end{array}$ & $\begin{array}{c}\text { The need to develop a plan along with } \\
\text { teacher's participation }\end{array}$ \\
\hline (ii) & STS Relations & $\begin{array}{c}\text { Integration of scientific, technological and } \\
\text { social aspects by means of field activities } \\
\text { studying real cases }\end{array}$ & $\begin{array}{l}\text { The need to develop integrated actions } \\
\text { within the school agenda/school curriculum }\end{array}$ \\
\hline
\end{tabular}


teaching. However, such partnership must be a two-way road. "Successful collaboration requires new partnerships among educators, researchers, and stakeholders, forging new actor networks in support of STS science education" (Aikenhead, 2009). It is necessary to integrate the activities to school practices, to the students' curriculum and plot plans along with the teachers in order to meet real demands of specific school's environment and not just the universities' demands.

The main goal of a SE lays on not only forming students that intend to perform further science related studies as scientists but forming all citizens (Aikenhead, 2003). Santos (2011) understands that the Science, Technology and Society (STS) movement has collaborated to a SE by consolidating its aim on developing conscious citizens. By reflecting upon the experiment performed with students and teachers, we can state that they might not choose a scientific career, but might become citizens aware of the environmental issues (problems, solutions and arenas of debate), as well as aware of the proper tools to take part in environmental management.

In addition, by performing this kind of activity it is possible to help by inserting the SL in the school's agenda. Such approach favors the work with students and teachers setting a connection between scientific topics and social issues, addressing its social relevance. Therefore, such activities bring up Roberts (2007) proposal which states that student/ teacher literacy is an ongoing formation process and becomes a citizen oriented education once taking the social role played by SE under consideration (Santos, 2007).

Once students are an integral part of society, they have the right to access all sorts of the knowledge available, in order to take part in their living place's environmental management process, aiming to become aware of the actions occurring in their surroundings, being able of participate in decision making. That is why it is demanding that they be in contact with a citizenship oriented education (Santos, 2007), with a view to recovering the political character of that educational approach. Such proposal is defined by up to date science teaching didactic tendencies that emphasize the importance of STS or Science, Technology Society and Environment (STSE) approaches, aiming to form active and responsible citizens, committed to society. According to Santos (2011), the STS movement for Science teaching contributed towards the insertion of socioscientific issues, by engaging responsible social actions, controversial ethical issues and contemporary environmental problems. However, it must be considered that the STS approach is linked to multidisciplinary issues such as those of political nature. Therefore basic school students and teachers must be included in interdisciplinary matrixes. Analyzing the case studied it is possible to identify that the contents that orientated the proposal of activities were guided by the scientific knowledge from limnological research performed in the Imboassica Lagoon, but these were permeated by the social and political issues present in the city of Macaé. The technology issue - through the Green Sewage Treatment Plant (STP) - was discussed as a viable proposal for the sewage treatment released into the lagoon.

Taking citizens by a SL viewpoint, it is possible to verify that there is other necessary information in order to develop the capacity to make decisions regarding political and economical aspects, by observing the problem from different perspectives. Thus, students should be taken deeper into these new activities we have presented. Specific matters such as: social groups mobilization, participation channels, access to the Imboassica's Technical Workgroup and to the municipality's Department of Environment were not essential for the activities, except for the participant's attendance and questioning (usually during the teachers' course), bringing contributions from their own experiences. Based on the fact that we have succeed in experiencing some of these aspects during the Freshwater Ecology course, addressed to undergraduate students, it is possible to state that such matters could be formally included in the activities, scheduling the participation and the presentation of public managers or of older local citizens.

Nevertheless, it is important to highlight the environmental questions that can influence school actions and those that address knowledge access resources, developing concepts that go beyond direct intervention (García and Priotto, 2009). School actions are limited by political aspects when environmental management enters the discussion. However, both the initial and the ongoing training given to the teachers should be politically oriented.

\section{Final Considerations}

According to Santos (2007), citizens' SL goes from literacy - in the sense of understanding basic principles of everyday phenomena - to the capacity of making decisions regarding issues related to science and technology (activities to which they are 
directly involved), no matter if they are personal decisions or those of public interest. Based on such sense, limnologists have a specific role to play: help understanding basic principles on aquatic environments' functioning, their degradation signs and their consequences to the human and the nonhuman life; in other words, help decreasing the asymmetry between knowledge produced by the academia and that produced by society, considering the importance of setting a debate among different scientific fields.

The current study argues that it is necessary to provide information and offer different experiences to the students by seeking ways to face the environmental problems based on limnological, social, historical, cultural, and technological standpoints, and achieved from an interdisciplinary viewpoint. So, it is demanding to influence the initial teachers' formation process while they are still at university as well as the continuous development of those already working in educational processes, they must be introduced to a more politicized view of the SE.

Summarizing, through the present article we state here that the educational work that provides SE by using the environmental problems suffered by coastal environments, to develop ongoing actions with teachers and students from elementary and high schools as well as with undergraduate and graduate students, gathering limnologists and researchers from the Human Sciences fields in a way to help them achieve a citizenship oriented scientific formation. Such reorientation sets challenges to limnologists whom produce scientific knowledge in fields that once articulated with other information and different approaches could help ensure better ways to use the water available on our planet.

\section{Acknowledgements}

We thank the Limnology Laboratory of the Universidade Federal do Rio de Janeiro for field assistance during performed activities and all teachers and students who participated of the activities.

\section{References}

AULER, D. 2011. Novos caminhos para a educação CTS: ampliando a participação. In SANTOS, W.L.P. AND AULER, D., orgs. CTS e educação científica: desafios, tendências e resultados de pesquisas. Brasília: Universidade de Brasília. 460 p.
AIKENHEAD, GS. 2003. Alfabetização científicotecnológica: um novo "paradigma"? Ensaio: Pesquisa em Educação em Ciências, vol. 5, no. 1, p. 1-16.

AIKENHEAD, GS.,2009. Research into STS science education. Revista Brasileira de Pesquisa em Educação em Ciências, vol. 9, no. 1, p. 1-21.

BOZELLI, RL., FERREIRA, DM., ESTEVES, FA., ROCHA, AM. and LOPES, AF. 2004. Educação Ambiental: Um processo embasado no conhecimento científico em longo prazo e determinante no cuidado com a natureza. In ROCHA, CFD., ESTEVES, FA. and SCARANO, F., orgs. Pesquisas de Longa Duração na Restinga de Jurubatiba Ecologia, história natural e conservaçâao. São Carlos: Rima. p. 361-374.

BOZELLI, RL., FERREIRA, DM., FREIRE, LM. and ROCHA, MAPM. 2011. Vivências em Ecologia: contribuiçôes à prática docente. $38 \mathrm{p}$.

ESTEVES, FA. 1998. Lagoa Imboassica: Impactos Antrópicos, Propostas Mitigadoras e sua importância para a pesquisa ecológica. In ESTEVES, FA., org. Ecologia das Lagoas Costeiras do Parque Nacional da Restinga de Jurubatiba e do Município de Macaé (RJ). Macaé: Núcleo de Pesquisas Ecológicas de Macaé (NUPEM)/Universidade Federal do Rio de Janeiro. $464 \mathrm{p}$.

ESTEVES, FA., FONSECA, ALS., CALIMAN, A., BOZELLI, RL., ENRICH-PRAST, A. and FARJALLA, VF. 2005. Projeto ECOLagoas: Um modelo de pesquisa, educação e cidadania. In ROLAND, F.; CESAR, D. and MARINHO, M., orgs. Liçôes em Limnologia. São Carlos: Rima. p. 115-125.

FERREIRA, DM. 1998. Ecossistemas do Parque Nacional da Restinga de Jurubatiba e do município de Macaé como Instrumento de Transformaçáo do Ensino de Ecologia no $1^{\circ}$ e $2^{\circ}$ graus da região Nortefluminense. In ESTEVES, F., ed. Ecologia das Lagoas Costeiras do Parque Nacional da Restinga de Jurubatiba e do Município de Macaé (RJ). Rio de Janeiro: UFRJ. p. 431-442.

GARCÍA, DS. and PRIOTTO, G. 2009. Educación Ambiental: aportes políticos y pedagógicos en la construcción del campo de la Educación Ambiental. Buenos Aires: Jefatura de Gabinete de Ministros, Presidencia de la Nación - Desarrollo Sustentable. $228 \mathrm{p}$.

LOPES, AF. and BOZELLI, RL. 2004. Os primeiros passos da educaçáo ambiental em um projeto de pesquisas ecológicas de longa duração: Reflexão sobre um caso. In ROCHA, CFD., ESTEVES, F., SCARANO, F., orgs. Pesquisas de Longa Duração na Restinga de Jurubatiba Ecologia, história natural e conservação. São Carlos: Rima. 376 p.

MARSICO, J., SANTOS, LMF., LOPES, AF., BOZELLI, RL. 2005. Educação Ambiental na Lagoa Imboassica. In Anais do X Congresso Brasileiro de Limnologia, 2005. 
PACHECO, MD., FREIRE, LM., LOUREIRO, CFB., BOZELLI, RL. 2008. Percepção de Problemas Ambientais Relacionados aos Usos dos Recursos Hídricos em Municípios do Interior do Estado do Rio de Janeiro. In Anais do Encontro Nacional da ANPPAS, 2008.

PALMA-SILVA, C. 1998. Crescimento e produção de Typha domingensis Pers na Lagoa Imboassica. 205-220. In ESTEVES, FA., org. Ecologia das Lagoas Costeiras do Parque Nacional da Restinga de Jurubatiba e do Município de Macaé (RJ). Macaé: Núcleo de Pesquisas Ecológicas de Macaé (NUPEM)/ Universidade Federal do Rio de Janeiro. 464 p.

PANOSSO, RF., ATTAYDE, JL. and MUHE, D. 1998. Morfometria das Lagoas Imboassica, Cabiúnas, Comprida e Carapebus: Implicaçóes para seu funcionamento e Manejo. In ESTEVES, FA., org. Ecologia das Lagoas Costeiras do Parque Nacional da Restinga de Jurubatiba e do Município de Macaé (RJ). Macaé: Núcleo de Pesquisas Ecológicas de Macaé (NUPEM)/Universidade Federal do Rio de Janeiro. $464 \mathrm{p}$.

PETRUCIO, MM. 1998. Caracterização das Lagoas Imboassica, Cabiúnas, Comprida e Carapebus a partir da Temperatura, Salinidade, Condutividade, Alcalinidade, $\mathrm{O} 2$ dissolvido, $\mathrm{pH}$, Transparência e Material em suspensão. In ESTEVES, FA., org. Ecologia das Lagoas Costeiras do Parque Nacional da Restinga de Jurubatiba e do Município de Macaé (RJ). Macaé: Núcleo de Pesquisas Ecológicas de Macaé (NUPEM)/Universidade Federal do Rio de Janeiro. $464 \mathrm{p}$.

ROBERTS, D. 2007. Scientific literacy/Science Literacy. In ABELL, SA. and LEDERMAN, NG., orgs. Handbook of research on Science Education, New Jersey: Lawrence Earlbaum, p. 729-781.

SANTOS, EG., BRANCO, CWC. and XAVIERDA-SILVA, J. 1998. Evaluation of environmental conditions in a Brasilian coastal lagoon (Lagoa Imboassica, RJ) and surrounding using geoprocessing.
Verhandlungen des Internationalen, vol. 26, p. 14991502.

SANTOS, WLP. 2007. Educação científica na perspectiva de letramento como prática social: funçôes, princípios e desafios. Revista Brasileira de Educaçáo, vol. 12, no. 36, p. 474-492.

SANTOS, WLP. 2008. Educação Científica Humanística em uma Perspectiva Freireana: resgatando a função do ensino CTS. Alexandria Revista de Educação em Ciência e Tecnologia, vol. 1,no. 1, pp. 109-131.

SANTOS, WLP. 2011. Significados da educação científica com enfoque CTS. In SANTOS, WLP. and AULER, D., orgs. CTS e educação cientifica: desafios, tendências e resultados de pesquisas. Brasília: Editora Universidade de Brasília. 460 p.

SAUVÉ. L. 2010. Educación científica y Educación Ambiental: un cruce fecundo. Enseñanza de las Ciencias, vol. 28, no. 1, p. 005-018.

SHAMOS, M. 1995. The myth of scientific literacy. New Brunswick: Rutgers University Press.

SILVA, JAM., PACHECO, MD., MARINHO, RV., FREIRE, LM., SIQUEIRA, M. and BOZELLI, R. L. 2009. Visão de Meio Ambiente e Problemas Socioambientais de um Grupo da Sociedade Civil e do Poder Público. In Resúmenes de participantes del IV Congreso Iberoamericano de Educación Ambiental, 2009.

STAKE, R. 1998. Case Studies. In DENZIN, N. and LINCOLN, Y. eds. Strategies of qualitative inquiry. California: Sage.

PRAIA, J., GIL-PÉREZ, D. and VILCHES, A. 2007. O papel da natureza da ciência na educação para a cidadania. Ciência \& Educação, vol. 13, no. 2, p. 141-156. http://dx.doi.org/10.1590/S151673132007000200001

UNESCO, 2011. Programa da UNESCO no Brasil 2011-2012. Brasília: Unidade de Publicaçôes da Representação da UNESCO no Brasil. 48 p.

YIN, RK. 2001. Estudo de Caso: Planejamento e Métodos. Porto Alegre: Bookman. 